\title{
Residential energy efficiency in Chile: Policies to reduce firewood dependency
}

\author{
Eficiencia energética residencial en Chile: \\ políticas para reducir la dependencia de la leña
}

Autores:

Alejandra Cortés-Fuentes* acortesfuentes@uchilefau.cl Behzad Rismanchi** behzad.rismanchi@unimelb.edu.au

* Faculty of Architecture and Planning, Universidad de Chile

** Melbourne School of Engineering,

The University of Melbourne

*Chile

**Australia

Recibido: 18/Mar/2019 Aceptado: 13/Nov/2019

\section{Abstract}

0 ver 10 million people in Chile are exposed to concentrations of Particulate Matter 2.5 and $10\left(\mathrm{PM}_{2.5}-\mathrm{PM}_{10}\right)$ in excess of the acceptable levels. The main source of emissions in the southern cities is the extensive use of firewood in the residential sector for cooking and heating. Low energy efficiency in buildings and inefficient heating appliances increase firewood combustion intensity and atmospheric pollution. This has led to many cities being declared saturated zones of particulate matter, requiring the implementation of various policies under an Atmospheric Decontamination Plan (ADP). The present research focuses on comparing three housing groups having different implemented strategies and subsidies for improving the energy efficiency of dwellings. A survey was designed to analyze occupants' fuel consumption patterns and their comfort perception before and after subsidies was applied. Also, it was registered the dwelling intervention to analyze the effectiveness of housing thermal retrofitting. Results showed that thermal retrofitting in housing is random, and does not respond to an accurate study of the interventions' energy efficiency.

Keywords: environmental policies, energy efficiency, housing retrofitting, firewood consumption, building code.

\section{Resumen:}

Más de 10 millones de personas en Chile están expuestas a concentraciones de material particulado 2.5 y 10 (MP2.5 - MP10) por sobre los niveles aceptables. La principal fuente de emisión en las ciudades del sur del país, es el intensivo uso residencial de leña para cocina y calefacción. La baja eficiencia energética de las viviendas y el uso de artefactos ineficientes aumenta la demanda de uso de la leña y la contaminación atmosférica. Esto ha llevado a declarar varias ciudades como zonas saturadas de material particulado requiriendo la implementación de Planes de Descontaminación Atmosférica (PDA). La presente investigación se enfoca en comparar tres grupos de vivienda con diferentes subsidios y estrategias de mejora en la eficiencia energética de la vivienda. Una encuesta fue diseñada para analizar los patrones de consumo de combustible y la percepción de confort antes y después de la aplicación de los subsidios. También se registraron las intervenciones en las viviendas para analizar la efectividad del reacondicionamiento térmico. Los resultados muestran que las intervenciones en las viviendas son aleatorias y no responden a un exhaustivo análisis de su eficiencia energética.

Palabras clave: políticas ambientales, eficiencia energética, reacondicionamiento térmico, consumo de leña, códigos de construcción. 


\section{Introducción}

In south Chile, over $80 \%$ of its urban households and almost $100 \%$ of rural households consume firewood, probably because it is four to seven times cheaper than other energy sources. The main use of residential firewood is for heating, followed by cooking (Gómez-Lobo, Lima, Hill \& Meneses, 2005). The combustion of humid firewood in inefficient appliances is currently responsible for atmospheric pollution in many southern cities, leading to severe health problems (Comisión Nacional de Energía [CNE], 2008).

A growing number of the southern cities have declared saturated zones for $\mathrm{PM}_{10}$ or $\mathrm{PM}_{25}$, or for both. Saturated zones are declared when at least one air quality safety regulation has been exceeded, based on measurements performed for a period of at least three years. This declaration triggers the requirement to design and implement an Atmospheric Decontamination Plan (ADP).

The Ministry of Environment has declared that over 10 million people are exposed to concentrations of $\mathrm{PM}_{2.5}$ that exceed acceptable levels. The primary source of emissions in the southern cities of the country is residential firewood combustion for cooking and heating. Thus, the ADP strategies are focused on replacing old and inefficient firewood appliances, certification of the firewood trade to ensure dryness and origin, and improving the insulation of the housing stock, to reduce the energy demand for heating (Ministerio del Medio Ambiente [MMA], 2014a).

The city of Temuco was declared a saturated zone for $\mathrm{PM}_{10}$ in 2005, and until then there had been no precedents of cities whose main sources of emission strength were firewood combustion for heating and cooking. The ADP for $\mathrm{PM}_{10}$ has been in effect since 2010, following the city's declaration as a saturated zone in 2005 . Over 10 years after the city was declared a saturated zone, this study aims to analyze, based on three different case studies, the ADP's implementation and impacts on Temuco.

The present research focuses on comparing three housing groups having different implemented strategies and subsidies for improving the energy efficiency of dwellings. The objective is to evaluate the impacts of the implemented ADP.

Results of this investigation reveal the program's performance and offer insight on possible failures/ limitations.

\section{Actions and policies developed in Chile}

\subsection{Current policies in force under the ADP}

Today in Chile, air pollution is measured in more than 25 cities. When the limits of pollutant concentration are ex ceeded, the city is declared a saturated zone as per the different pollutants that have exceeded the permissible concentrations. A process then follows in which local au thorities design and approve an Atmospheric Decontamination Plan (ADP). The Plan usually contains a diagnostic of the main pollutant emission sources and various policies to be implemented. Implementation of ADPs started in 1992 with the aim of lowering pollutant concentrations to acceptable levels, to comply with the national norm (MMA, 2014a).

Since 2012, the Ministry of the Environment has operated monitoring stations. Due to the importance of the issue, it has been deemed necessary to improve and increase the amount of air quality monitoring equipment, mainly for $\mathrm{PM}_{2.5}$, in cities with more than 100 thousand inhabitants, in order to strengthen the monitoring system in accordance with the country's needs. At the same time, one of the priority objectives of this work is to enable public online access to the recorded information (MMA, 2012). Considering a compensation of particulate matter and the type of emission sources in different parts of the country, it is assumed that, on average, $14 \%$ of $\mathrm{PM}_{10} \mathrm{CO}$ rresponds to $\mathrm{PM}_{2.5}$ in the northern zone, $50 \%$ of $\mathrm{PM}_{10} \mathrm{co}-$ rresponds to $\mathrm{PM}_{2.5}$ in the central zone, and $70 \%$ of $\mathrm{PM}_{10}$ corresponds to $\mathrm{PM}_{2.5}$ in the southern zone. In large urban areas such as the city of Concepcion, it is assumed that $50 \%$ of $\mathrm{PM}_{10}$ corresponds to $\mathrm{PM}_{2.5}$ (MMA, 2012).

Upon reviewing all the official decrees of ADPs issued by the Ministry of Environment and in effect (Fig. 1), it was observed that in the northern part of the country, the main decontamination policies were focused on the industry as the main source of emissions (mostly mining), with PM and SO2 as the pollutants exceeding the norms (Ministerio Secretaría General de la Presidencia - Comisión Nacional del Medio Ambiente [Minsegpres-Conama] 1998a; 1999; Minsegpres, 1999; 2001; MMA, 1992; 2010; MMA, 2014b). In Santiago, the capital city, where almost half of the nation's population lives, the main policy actions are focused on transport (public and private), industry, and the residential sector (Minsegpres, 2010a; MMA, 2003; Minsegpres-Conama 1998b). The southern cities follow the same policy pattern, with the residential sector as the leading source of $\mathrm{PM}_{10}$ and $\mathrm{PM}_{2.5}$ emissions (Minsegpres, 2010b; MMA, 2013a, 2013b; 2016a; 2016b; 2016c; 2016d)

The Ministry of Environment acknowledges that the southern cities are a major challenge, since pollution rises as they grow. Despite there being many ADPs implemented and others in development process, in many cities the $\mathrm{PM}_{2.5}$ concentrations still exceed the norm (MMA, 2014a). Moreover, it is likely that cities with under 100 thousand inhabitants that have not yet been monitored have the same problems of air pollution. 
Temuco is an emblematic case, as it was declared a saturated zone for $\mathrm{PM}_{10}$ in 2005, and there were no precedents of cities whose main emission source strength was firewood combustion for heating and cooking. According to data from recent studies, in the city of Temuco, $93.6 \%$ of $\mathrm{PM}_{2.5}$ comes from wood fuel combustion in the residential sector (MMA, 2013a), and other studies have considered the city a mono source contamination case (Cereceda-Balic, et al., 2012). In 2013 the city was declared a $\mathrm{PM}_{25}$ saturated zone, and since 2015, a new and updated ADP has been in force for the city, for both $\mathrm{PM}_{10}$ and $\mathrm{PM}_{2.5}$.

The same diagnostic and policies to be implemented are set out in other ADPs for $\mathrm{PM}_{10}$ and $\mathrm{PM}_{2.5}$ in the southern cities. It is acknowledged that the four factors contributing to emissions of residential firewood combustion as the main source of pollution are a) the commercialization and use of firewood that does not comply with the minimum standards; $b$ ) the use of wood in old appliances with lack of appropriate technology; c) the high demand for firewood for heating due to poor building insulation and d) the behaviour of firewood consumers (burning preferences, opening-closing air flow, volume of wood combusted etc.). In relation to residential combustion, the main actions are:

- Regulation of the use, trade and quality of firewood - Regulation of the quality of residential appliances that use firewood

- Regulation of the thermal efficiency of the housing stock - Education and information for firewood consumers

\subsection{The Firewood Trade}

The preference for firewood as heating fuel is explained to a large extent by its low price compared to alternative fuels; moreover, the informal firewood trade makes it even cheaper. It is estimated that if tax evasion in this market were eliminated, it would mean additional revenues for the government of over USD \$15 million a year (MMA, 2012). In the region extending south from $36^{\circ}$ latitude south (Biobío Region), firewood purchases in the urban residential sector could total over 500 thousand cubic meters a year on average (Gómez-Lobo et al., 2005).

To address these problems, in 2007 the government created a private-public initiative, with support from the European Union, called the National System of Firewood Certification (Sistema Nacional de Certificación de Leña - SNCL) which has set quality standards for the firewood trade. This initiative strives to reduce forest degradation and environmental pollution.

The challenge is to control the informality of the market, as this is the main obstacle for achieving sustainable firewood use. The four main targets are: a) compliance with the forestry law, to guarantee that the wood is produced through a process of sustainable exploitation management; b) information on the origin of the firewood c) $20 \%$ humidity; and d) adequate customer information (species, humidity and volume).

It is very difficult for distributors to perform the drying process in a short period of time, mainly because of the humid climate in the region.

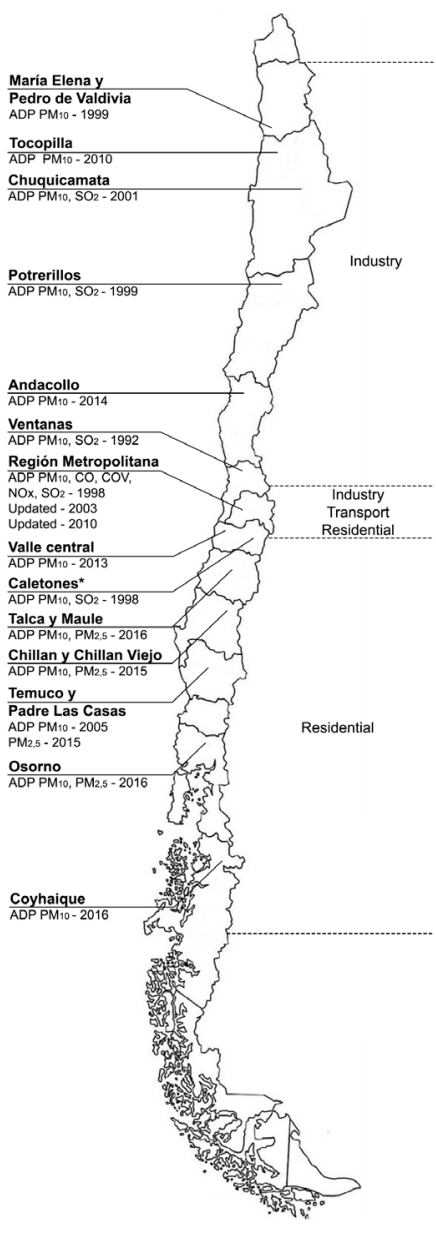

"Caletones: Main line of industrial action.

Figure 1: ADPs Implemented in Chile until 2016 Source: Authors

Distributors need to store the dry wood inside covered spaces and wait to sell it, which drives up the final selling price and discourages retailing of certified wood.

Currently, $86 \%$ of the firewood is extracted from native forests; this is therefore a very important aspect to regulate. It is not mandatory to use certified firewood and there are as yet few certified suppliers (Schueftan \& González, 2015). According to the data managed by the SNCL (El Mercurio, 2014a), only $23 \%$ of firewood consumption in big cities is certified. This figure could be lower in rural areas, where distributors are more difficult to find.

\subsection{Appliance Replacement}

The upgrading of appliances was being done through the certification of all new appliances installed in the city and through the promotion of voluntary changes of the old stock, with the support of a government subsidy. The subsidies for stove replacement mainly considered heating and cooking appliances. The beneficiaries of a subsidy were required to attend a training workshop to learn adequate stove operation. It was compulsory to relinquish the old appliances upon installation of their replacements. 
The Ministry of Environment approved the standard of particulate matter emissions for appliances that combust firewood and pellets (2014 and 2016, respectively), to improve the technology market of heaters, enhance energy efficiency and reduce emissions. With the entry into effect of the standard, all heater manufacturers or importers need to certify their products before they can be marketed. The certification accredits that the product complies with the requirements for PM emissions, energy efficiency and safety (MMA, 2017).

Some studies have foreseen that the removal of cook stoves in low-income households may pose significant difficulties. First, because the cook stove is used for both, cooking and heating, hence its removal implies its replacement with two new appliances, thus increasing household expenditures. Results of economic forecasts indicate that, despite the subsidy, the resulting savings in operating costs are low and even negative in the low-income group (Universidad de la Frontera [UFRO], 2009). In addition, the replacement subsidy only applies to houses and excludes apartments. Thus, appliance replacement can dramatically change the cost of domestic energy consumption. This change in the price dynamic has not been considered in the current programs (Schueftan \& González, 2015).

\subsection{Building Code}

The Urban Planning and Housing Ministry began enforcing an Energy Building Code in 2000 for new residentia constructions, based on seven thermal zones defined according to location and altitude. At this first stage, the Code covered just loft insulation. Since 2007, the Code has been extended to a second stage to cover exposed floors, external walls and windows. The regulations specify maximum $U$ values as $\mathrm{W} / \mathrm{m} 2 \mathrm{~K}$, but do not as yet specify values for ground heat transfer, air infiltration, ventilation or heating (Collados \& Armijo, 2009). In addition, the thermal insulation standards stipulated in the regulations do not compare well with European ordinances for similar weather conditions, neither with the recommended standards in several studies performed in Chile.

The necessary demand for heating residential buildings is considered excessively high and the thermal insulation standards are clearly not adapted to the climate solicitations in every locality (Bobadilla, Díaz, Figueroa \& Arriagada, 2014). The third stage is still pending and contemplates a thermal energy certification process. The certification system would evaluate the energy performance of housing, classified according to seven levels: from $A$ to $G, G$ being the least efficient housing. Leve $E$ would represent the standard of a house built under the current energy building code, mandatory since 2007. Specifically, the levels are:

- Level A, with an $80 \%$ energy demand reduction from baseline

- Level B, with a $60 \%$ energy demand reduction from baseline

- Level C, with a 50\% energy demand reduction from baseline

- Level D, with a 30\% energy demand reduction from baseline
- Level $\mathrm{E}$ is the baseline, representing a house in compliance with the 2007 Building Code

This certification is a voluntary tool for introducing energy efficiency into the construction market. Today, new buildings are granted building permits without provision for a heating system, and consequently the most common appliances used in the southern cities are old and inefficient wood burning heaters. Tenants must manage their own heating needs and there is no technical or financial support available. Evidence from other research studies has shown that the 2007 Energy Building Code was quite deficient compared to the standards of developed countries whose climate is similar. The reduction potential evaluated in such studies reached $62 \%$ heating energy consumption compared to the Chilean standard (Schueftan \& González, 2013). The Chilean standard is stiIl lacking in aspects such as thermal bridges, airtightness, condensation, ventilation, vapor and humidity barriers, among others.

Energy efficiency in the residential sector is a priority of the European Union, with its target of achieving a 27\% energy savings in buildings in the residential sector in $\mathrm{EU}$ countries by 2020 (Pérez, Flores \& Calama, 2015). The restoration of housing is emerging as a potential key area for the reduction of energy consumption in most countries. In Chile, the Urban Planning and Housing Ministry developed a subsidy that funds the refurbishment of the building envelope.

Improvements in the thermal efficiency of the housing stock have been implemented through an already existing subsidy programme developed by the Urban Planning and Housing Ministry that is focused on financial assistance for retrofitting existing buildings, consisting of insulating the thermal envelope of housing to improve energy performance, and thus meet the 2007 Building Code. This program, called "Programa de Protección del Patrimonio Familiar" (Family Equity Protection Programme), provides for the refurbishment of social housing with an appraised value equal to $650 \mathrm{UFs}^{1}$. The funding ranges from 100 to 130 UFs to improve the building envelope (walls, ceiling, roof, floor, infiltrations, and so on). Funding is calculated based on the families' socioeconomic status.

\section{Materials and Methods}

In Chile, each municipality has the authority to issue housing construction permits in accordance with its own regulation and urban planning system. Subsidies are granted by the regional authority of the Urban Planning and Housing Ministry. It is not a requirement to publish information on private or public projects, nor to publish statistical information on housing type, socioeconomic income of subsidy recipients, or any other information regarding residential growth. It is common for the information to be dispersed, or even to simply be unavailable. This state of affairs in fact became even worse after the

${ }^{1}$ The Unidad de Fomento (UF) is an indexed unit of account used in Chile. The exchange rate between the UF and the Chilean peso is adjusted daily for inflation, so that the value of the Unidad de Fomento remains constant on a daily basis during periods of low inflation. 
Chilean National Statistical Institute declared the 2012 Census invalid.

The present research focuses on comparing three housing groups having different implemented strategies for improving the energy efficiency of dwellings. A case study is an empirical inquiry which, in the social sciences, enables investigating a contemporary phenomenon within its real-life context (Platt, 1992). The "case study" methodology was chosen since Temuco is currently the only city with a middle-income housing group that received financial support for thermal housing retrofit (Ministerio de Vivienda y Urbanismo Minvu [Minvu], 2015). The chosen cases are located in the urban area, because the ADP has a limited implementation area, which is urban.

To locate the three cases, it was necessary to carry out fieldwork and interviews with local public services. Thus, at the time of the research, Temuco had two emblematic and unique cases: a middle-income group with subsidies for thermal retrofit (not the case elsewhere, as subsidies are normally given to social housing only), and a middle-income group with energy certified housing (the only group of this kind in the city, as certification is voluntary). The kind of heating or cooking appliance was not a criterion for choosing the case studies, as the building envelope quality was the main focus of this study. In addition, this information had to be collected in the fieldwork, as there is no public available information of the families that have replaced their appliances with an ADP subsidy.

Thus, results are based on qualitative data gathered through surveys performed in the following three different housing groups:

- Ten social housing units, with financial support for building retrofitting to install insulation in the thermal envelope (units built between 2013 and 2015).

- Ten middle-income housing group units, with financia support for building retrofitting to install insulation in the thermal envelope (units built between 2014 and 2015)

- Seven middle-income housing units with thermal energy certification (units built in 2012)

The survey was designed as a semi-structured instrument and based on occupants' consumption patterns and perception. It gathered the following information:

- Type of intervention performed with the subsidy for building retrofitting (insulation of walls, roof, window replacement and so on). This was queried in the social and middle-income housing groups, as both received the subsidy.

- Type of heater used before and after dwellings received the subsidy for appliance replacement.

- Firewood consumption in $\mathrm{m} 3$, before and after the subsidies.

- Residents' perception of indoor thermal comfort. This question was to determine whether residents could perceive changes after the refurbishment.
The energy certified housing group, which did not receive subsidies, was asked about the type of heater, firewood consumption, and the residents' perception of indoor thermal comfort. The survey data was used to calculate average $\mathrm{PM}_{10}$ emissions for each of the three groups. Data were disaggregated based on the information $\mathrm{CO}^{-}$ llected on each dwelling for the social and middle-income groups to estimate the emissions before and after the subsidy for retrofitting, as well as with and without subsidies for heating appliance replacement. Although the average yielded from the groups cannot be considered statistically representative of the entire universe of dwellings in the city, it does offer insights into possible trends following subsidy implementation. Moreover, the comparison of three different groups can help to identify energy efficiency patterns. The energy certified group received no subsidies since they were designed and built according to high insulation standards. Subsidies are given for housings without minimum insulation standards. This group was therefore the benchmark for evaluating the impacts of the subsidies applied in the other two groups. Calculations also considered the variable of humidity of the firewood, as the emission factor is significantly higher in humid firewood for all classes of appliances (see emission factor in Fig. 3). The present research found the average $\mathrm{PM}_{10}$ emissions for each group considering:

- Baseline Emissions: The average $\mathrm{PM}_{10}$ emissions before application of the subsidy for building retrofitting for each housing group. This was calculated using the information collected in surveys, in relation to the $\mathrm{m}^{3}$ of firewood used before the refurbishment. For the energy certified housing group, the information was based on current patterns of firewood combustion.

- Emissions After Retrofit: The average $\mathrm{PM}_{10}$ emissions after application of the subsidy for building retrofitting in each housing group, but only for dwellings that have not replaced their heating appliances. This disaggregation enables analyzing the emissions reduction exclusively resulting from the building retrofit and making a comparison with the benchmark group.

- Emissions After Retrofit and Heater Replacement: The average $\mathrm{PM}_{10}$ emissions after application of the building retrofitting subsidy and appliance replacement in each housing group. This average is the current status of each group and considers the current $\mathrm{m}^{3}$ of firewood being used.

To calculate average emissions per group it was necessary to consider the number of houses surveyed; socioeconomic strata; type of firewood combustion appliance; months of use; emission factor with dry and humid wood; efficiency reduction factor; average firewood consumption; firewood density (Fig. 2).

This research considered the maximum Emissions Factor for each appliance registered in various studies (Comisión Nacional del Medio Ambiente [Conama], 2004). The available information is only given in $\mathrm{PM}_{10}$ and not in $\mathrm{PM}_{25}$, reason why the evaluation of this study are done in $\mathrm{PM}_{10}$. However, several studies have shown that $70 \%$ of $\mathrm{PM}_{10}$ corresponds to $\mathrm{PM}_{2.5}$ in the southern zone of the country (MMA, 2012). 


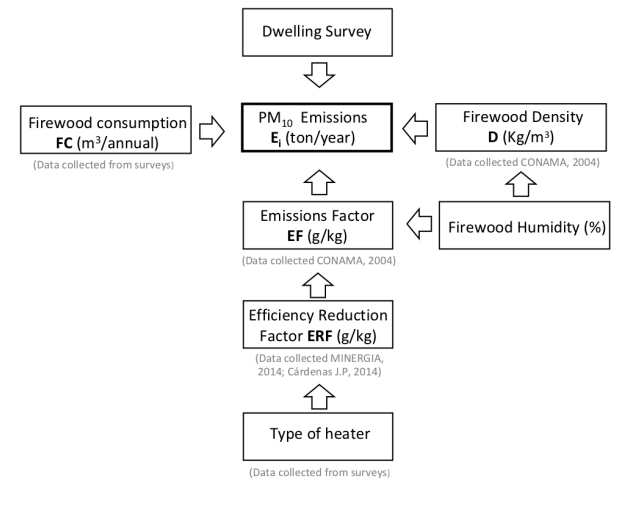

Figure 2: General Procedure for Calculating MP Emissions

Source: Authors with data from Conama 2004

The Emission Factor varies depending on firewood humidity content. Dry firewood is considered as having humidity content equal to or less than $20 \%$, while anything above this figure is humid firewood. Firewood density also varies according to humidity: dry firewood has an average density of $700 \mathrm{~kg} / \mathrm{m}^{3}$, while humid firewood has an average density of $800 \mathrm{~kg} / \mathrm{m}^{3}$ (Conama, 2004).

The Efficiency Reduction Factor (ERF) is based on the firewood combustion of each type of appliance (see type of appliance in Fig. 3). Based on prior research the factors are: Salamandra (Franklin stove) 35\%, Cook stove 35\%, Simple Combustion 60\%, and Double Chamber Combus- tion 70\% (Ministerio de Energía [Minergia], 2014; Cárdenas, Araneda \& Beaumont, 2014). With this data, it was possible to calculate the emission of each surveyed house with the following formula (Cárdenas et al., 2014):

$$
E i=E F^{*} A L^{*}(1-E R F / 100)
$$

The formula expresses the product of the Emission Factor (EF in Fig. 3), Activity Level ( $\mathrm{m}^{3}$ of firewood*density) and the Efficiency Reduction Factor (ERF).

\section{Results}

Type of Building Retrofitting: As shown in Figure 4, before the implementation of subsidies, just one home had thermal insulation in the roofing, which corresponds to a middle-class dwelling. Following the intervention, all of the middle-class houses had improved, but not all of the social housing units. The material most often used turned out to be glass wool, and for the energy certified house, the material used as the initial design solution was mineral wool insulation. However, during the fieldwork, technical details were not obtained, such as the installation solution, density and thickness of the insulating material.

Wall Insulation: Figure 5 shows that just one of the housing units has thermal insulation on the walls, installed when it was first constructed. After application of the subsidy, wall insulation was installed attached to the wall.

Where the partition walls were of wood, glass wool insulation was used, and in the houses with brick masonry

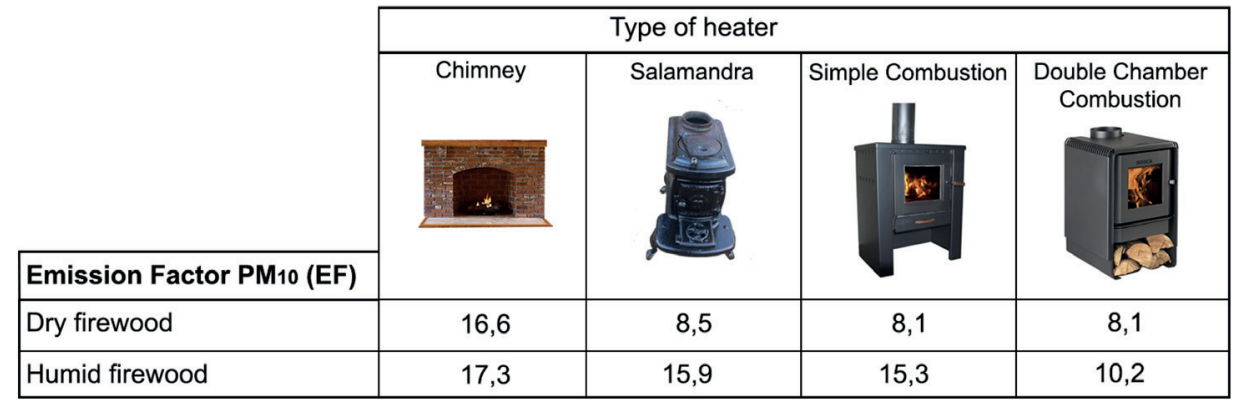

Figure 3: Maximum MP10 Emissions Factor per Appliance Source: Authors with data from Conama 2004

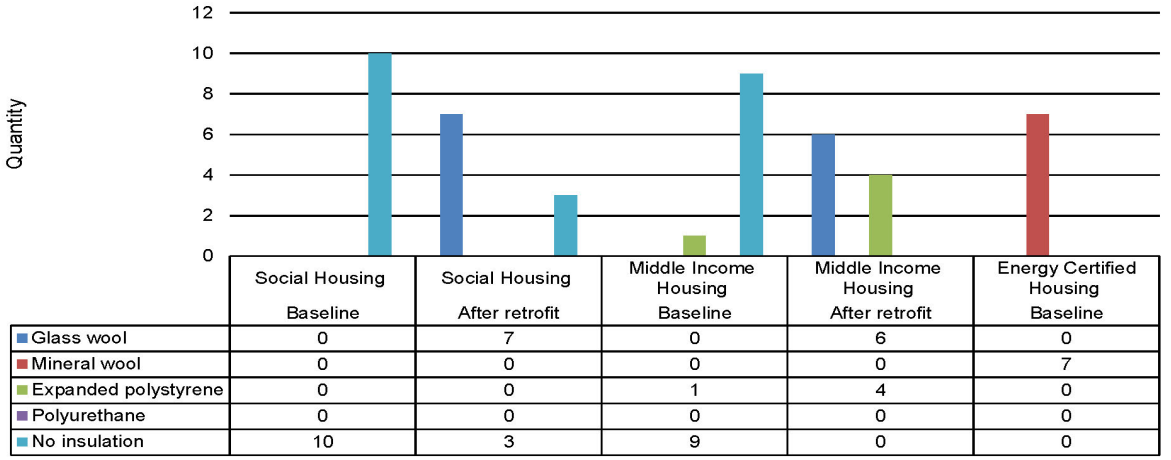

Figure 4: Roof Insulation

Source: Authors 


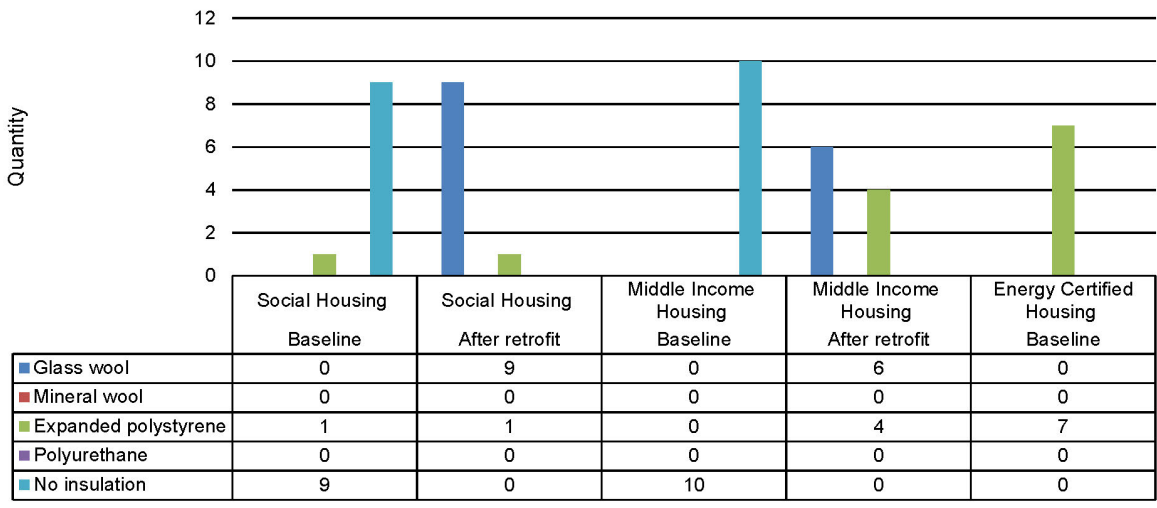

Figure 5: Wall Insulation

Source: Authors

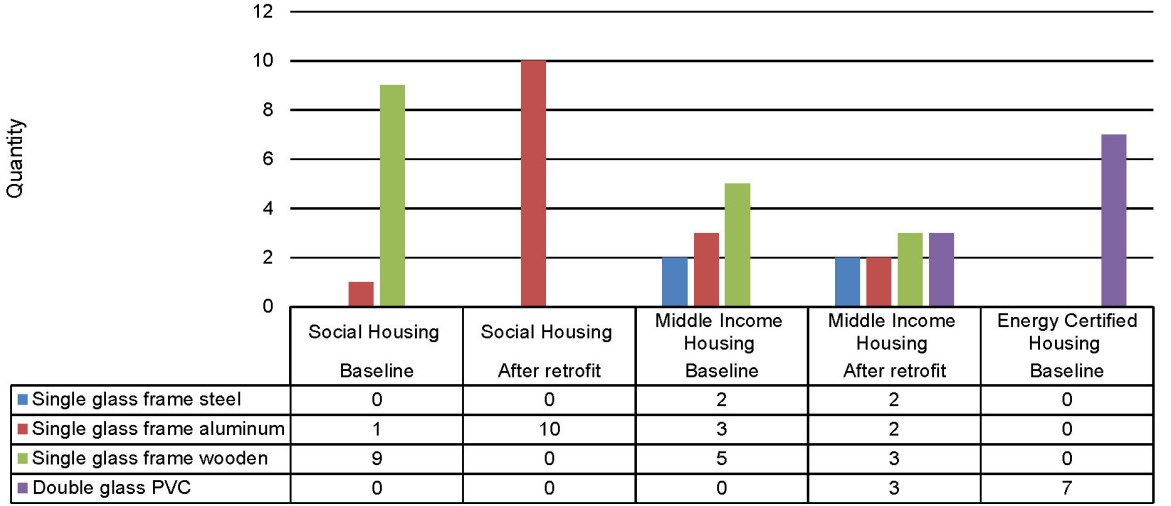

Figure 6: Windows replacement

Source: Authors

expanded polystyrene. The energy efficiency certified dwelling had expanded polystyrene insulation.

Window Replacement: As Figure 6 illustrates, most of the social housing units initially had single-glass windows with wood frames.

After the application of the subsidy, the wood frames were replaced with aluminum frames to prevent heat loss from air infiltration. In the middle-class dwellings, the change of windows was infrequent, but there were cases in which they were replaced with double-glass windows with PVC frames (financed privately). This same window typology was used for the energy certified dwellings in their initial design solution. The double glass allowed for better benefits of thermal insulation and energy savings, as well as the PVC reducing the thermal bridges, compared to the aluminum frames.

Type of Heater Used: Figure 7 shows that all social housing owners surveyed used wood as their primary heating fuel. The middle-class housing units were observed to have more variety in typologies of heating, such as gas, paraffin and electric heaters, mirroring the case of the energy certified dwelling. After the subsidy was applied for thermal retrofitting, there were instances of users applying in parallel for the subsidy for heating appliance replacement, applying both interventions.
The results of the survey showed that just one out of the 10 social housing units implemented a heater replacement with the available subsidy, while in the 10 midd le class housing units, four applied the same subsidy to replace their old technology. The reason could be that there are some advantages of the cook stove more difficult to quantify, i.e., their indirect use for hot water and clothes drying. In addition, the cook stove has strong cultural roots and it is estimated that the acquisition and use of cook stoves does not answer to the typical economic factors of the markets - price, cost and competitiveness - but to maintain the traditional habits of use (Ambiente Consultores, 2007).

Firewood Consumption: Firewood is the fuel most used for heating dwellings. In Temuco, $88.9 \%$ of the total number of houses in the residential sector are consumers of firewood (Corporación de Desarrollo Tecnológico [CDT], 2015).

As Figure 8 shows, according to the survey results, the consumption of firewood dropped $43 \%$ in the social housing group and $58 \%$ in the middle-class housing group. This reduction was higher in the middle-class housing group with more acceptance of replacing wood heaters with ones that use pellets. However, the cost of the pellets cannot be absorbed by the social housing group, as pellets are much more expensive compared to the cost of 
firewood. The average consumption of firewood in the energy certified housing group was considerably lower since the group used a more varied typology of heaters and just two of the houses used firewood combustion.

Perception of Thermal Comfort: The average thermal comfort perception in the various types of housing was based on the value ranges indicated by each survey respondent. This value range fluctuates between 1 and 10, where 10 indicate the optimum perception. Perception in social housing increased positively from 3.6 to 7.2 , before and after retrofit correspondingly. The same occurred in the middle-income housing, increasing the thermal comfort perception from 3.9 to 7.9. The energy certified housing had a 7.7 grade.

It was observed that for both subsidized groups, the perception of thermal comfort was deficient before application of the subsidy and that after its application all the residents' evaluations improved.

As shown in Figure 9 , the baseline emissions of $\mathrm{PM}_{10}$ in the social housing group were the highest of the three groups surveyed. This is directly proportional to the $\mathrm{m}^{3}$ of firewood consumed and the appliance type. The social housing group had the most number of cook stoves and salamandras (Franklin stove). The middle-income housing group registered more frequent use of simple and double-chamber stoves, as well as gas or paraffin stoves. The energy certified housing group made more frequent use of double-chamber stoves and required fewer hours to keep their homes comfortable.
When calculating the average $\mathrm{PM}_{10}$ emissions after application of the subsidies for building retrofit, annual average emissions were reduced by $31.8 \%$ in the middle-income group and by $26.6 \%$ in the social housing group.

There is an even more significant reduction of $\mathrm{PM}_{10}$ emissions when appliance replacement is factored into the calculations. This is especially true because all replacements included a new pellet stove, which reduced emissions by up to $10 \%$ more than traditional appliances. Social housing units reduced their emissions by $43.1 \%$, while middle-income units reduced emissions by $52.6 \%$. This is primarily true because more houses in this group applied the subsidy for appliance replacement.

\section{Discussion}

Policies implemented with the ADPs require critical in-depth evaluation. The reduction potential in energy consumption for heating in social housing is shown to be very large, reaching $62 \%$ reduction compared to the current Chilean Norm from 2007 and 77\% if stricter regulations would be targeted (Schueftan \& González, 2013).

The authorities of environment, housing, energy and health are strongly focusing firstly on enforcing firewood certification, and secondly on stove replacement. The fact that substantial potential for reduction lies on thermal refurbishments, have not yet been recognized (Schueftan \& González, 2015). In addition, the subsidies for housing retrofitting have not been monitored in order to show the

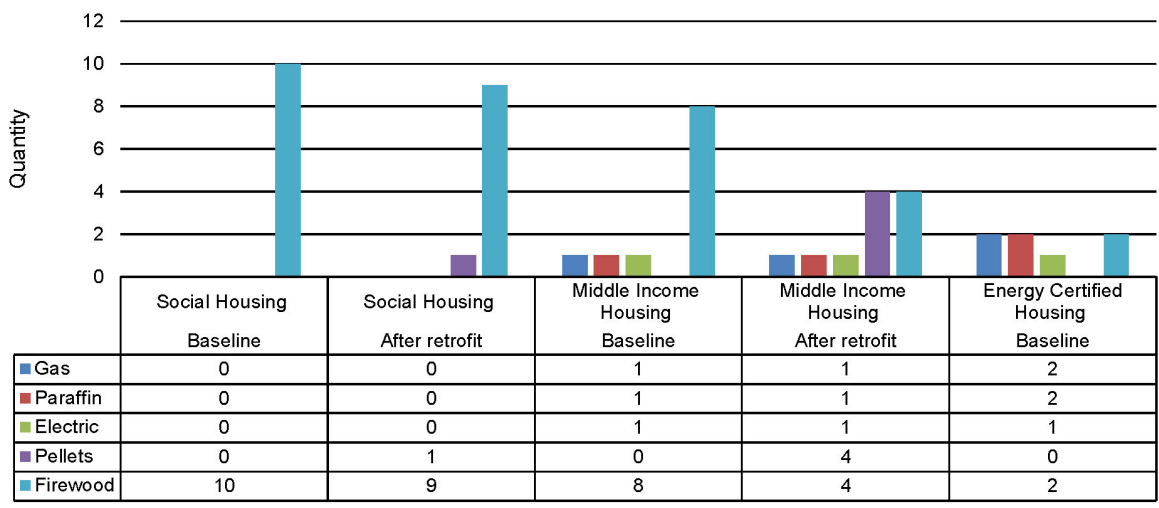

Figure 7: Type of heater used

Source: Authors

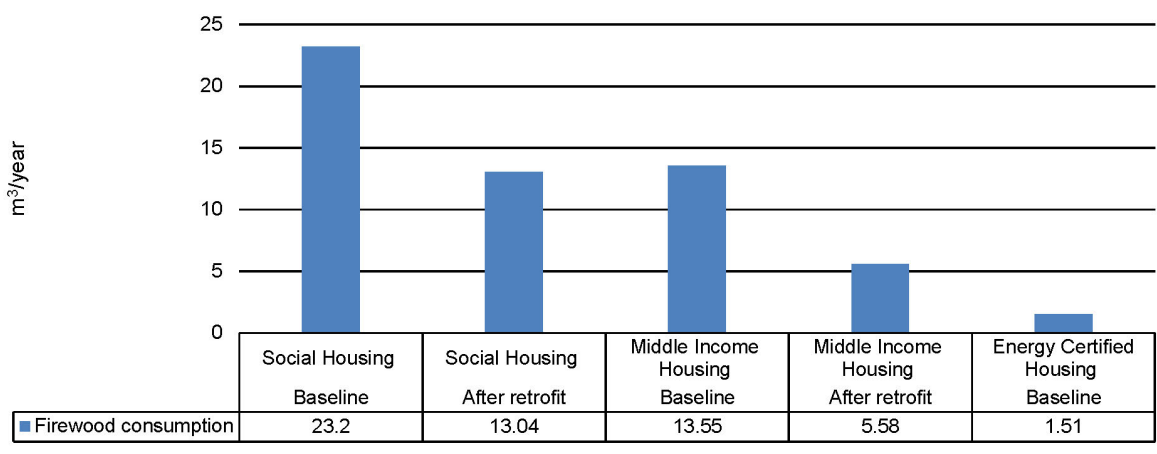

Figure 8: Firewood consumption

Source: Authors 
energy efficiency achievements. The results of this study show that there is a lack of information, both social and technical, in the implementation of the solutions.

More investments should be made to monitor and collect in situ information regarding the energy behaviour of different socioeconomic groups, the acceptance of the implemented policies and subsidies, and building energy performance after thermal retrofits. Some studies have demonstrated lack of public awareness (Hofflinger et al., 2019) and the importance of sociodemographic and psychological factors in the decision to replace heating systems (Boso, Oltra \& Hofflinger, 2019).

The social housing group, after subsidies, kept non-insulated roofs and continued using firewood as their primary energy source. Today, there is no available data on the technical aspects of how building retrofit is performed (design, construction, materials, cost and efficiency, etc.). Also, it is important to gather sufficient information on indoor air quality and temperature after the application of subsidies. As well as to implement massive surveys to study the main appliances used for heating in rural and urban areas, firewood consumption and trade, available fuels, peoples' thermal comfort, etc.

This research project collected data through surveys on dwellings that different subsidies had been applied to, and results show that appliance replacement has been better received by middle-income families. Low-income people can be drastically affected if the new heating system requires more expensive fuel and if certified firewood prices rise. This is more evident in those families using a cook stove, which allows heating and cooking with the cheapest available fuel. A large percentage of people live on the minimum or nearly minimum wage (around US\$400 per month in 2013), and if firewood prices increase, a large number of people would suffer a significant drop in their heating budget capacity and, consequently, their thermal comfort and quality of life would fall as well (Schueftan \& González, 2013).
Heater replacement needs to be thoroughly evaluated, in relation to price and availability of other fuels. In southern cities, heating with pellets has been a very popular option among middle- and high-income families. However, in the winter of 2014 the demand for pellets had doubled compared to the previous year and producers failed to meet the market demand (El Mercurio, 2014b). Compared to other fuels, the cost of firewood is around 4 to 5 times cheaper than kerosene, LPG or electricity per unit of energy (Reyes, et al., 2019)

For this reason, a large number of people use and prefer firewood as their main energy source. Also, it is a readily available natural resource in southern Chile (CDT, 2010). A policy to apply pressure to raise firewood prices would affect mainly rural and low-income families.

\section{Conclusions}

In the last decades, Chile has been showing an increasing problem of atmospheric pollution due to residential firewood combustion in most of the southern cities. The main reason for this huge firewood demand, is the poor insulations of houses which demand more energy for heating, bad quality and inefficient heater appliances, and an informal market that trades humid firewood. Atmospheric pollution has also increased health risks in the population. This has caused constant atmospheric emergency decree in the last years, which results in cities declared as saturated zone by particulate matter.

The Atmospheric Decontamination Plan, which is designed for each city, has had similar answers for the same problem along the southern cities of the country. Such as increasing the number of subsidies for thermal retrofit in housing, supporting the replacement of old heater appliances and regulating the market of humid firewood. However, there is no enough evidence to show how much these strategies can contribute to reduce pollutant emissions.

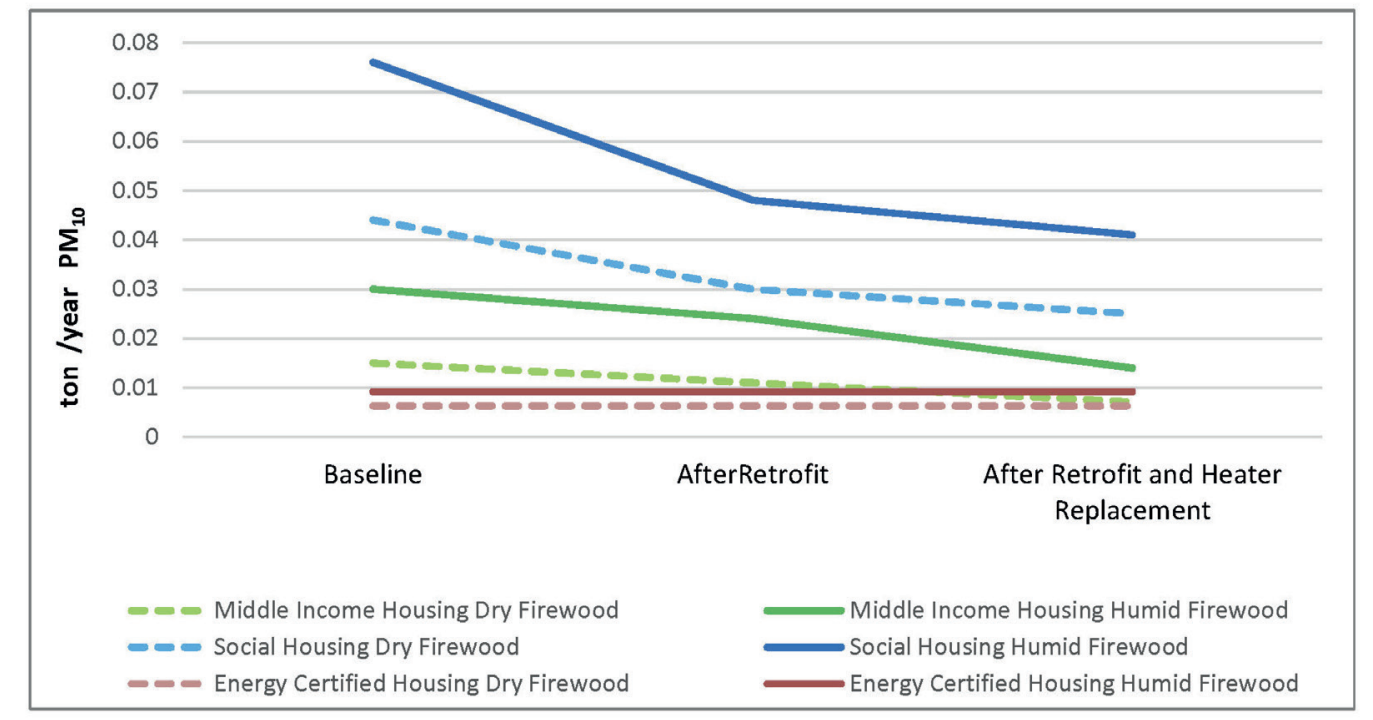

Figure 9: Emission reduction

Source: Authors 
The results of this research are based on surveys, which collected data about household firewood consumption patterns, before and after the subsidies. This allowed, among other results, having an average emission for each socioeconomic groups that was surveyed, as a baseline to compare emission after subsidies were applied Results have shown that after the building retrofit, particulate matter emission can be reduced in around a third compared with the baseline. While after the heater appliance replacement, can reach almost half of emission reduction.

Baseline emissions projected only to the 52,000 subsidies considered in the ADP, were calculated by taking a baseline average emission from both groups, social and middle class housing. Although there is an important emission reduction with both strategies, projections done in this research suggest that, even if both strategies are applying to the 52,000 houses for building refurbishment, is not enough to comply with the target reduction set by Conama (2004) estimated of 2,400 tons/year. But, in an ideal scenario, if buildings reach the energy certified standard, and dry firewood is used, reductions can reach even half of the target.

The results of this study have shown the different impacts on emission reduction that the three case studies have had. Despite the reduction produced by subsidies for housing retrofit, the energy certified house has better energy performance. This is significantly important, as results have shown that the thermal retrofitting of the surveyed houses falls somewhat short of being the most efficient solution. At the same time, the results demonstrate that more efficient housing construction with high insulation standards are required to be put in place from the beginning, rather than having to perform refurbishments later.

Improving the construction code and building retrofitting standards can then have a significant impact on emission reductions in Chile's southern cities. All these points need to be evaluated for the future design and implementation of ADPs in the southern cities, so as to eliminate prescriptive policies and focus public investments on strategies that will exert higher positive impacts on the environment and societal well-being.

\section{Acknowledgements}

This work was supported by the Academic Productivity Support Program, PROA-VID 2016, Universidad de Chile; and the Energy Program Conicyt- Minergia 2018.

Cómo citar este artículo/How to cite this article: Cortés-Fuentes, A. y Rismanchi, B. (2020). Residential energy efficiency in Chile: Policies to reduce firewood dependency. Estoa. Revista de la Facultad de Arquitectura y Urbanismo de la Universidad de Cuenca. 9(17), 57-68. doi: 10.18537/est.v009.n017.a05

\section{Bibliographic references}

Ambiente Consultores. (2007). Programa de Inversión Pública para Fomentar el Reacondicionamiento Térmico del Parque Construido de Viviendas. Final Report (587368-LE06). Santiago, Chile: Gobierno de Chile. Recovered from http://old.acee.cl/576/articles-60897_doc_pdf.pdf

Bobadilla, A., Díaz, M., Figueroa, R. \& Arriagada, R (2014). Proposal of Acceptable Air Tightness Classes for Buildings in Chile. Journal of Construction, 13 (1), 15-23. doi: 10.4067/S0718-915X2014000100002

Boso, A., Oltra, C. \& Hofflinger, A. (2019). Participation in a programme for assisted replacement of wood-burning $T$ stoves in Chile: The role of sociodemographic factors, evaluation of air quality and risk perception. Energy Policy, 129 (1), 1220-1226. doi 10.1016/j.enpol.2019.03.038

Cárdenas J.P., Araneda C. \& Beaumont J.C. (2014). Evaluación del Plan de Reacondicionamiento Térmico en Temuco y Padre Las Casas. Revista Ingeniería de Obras Civiles - RIOC, 4 (1), 18-25.

Cereceda-Balic, F., Fadic, X., Llanos, A.L., Guevara, J.L., Vidal, V., Díaz-Robles, L.A., Schiappacasse, N. \& Etcharren, P. (2012). Obtaining PAHs concentration ratios and molecular markers for residential wood combustion: Temuco a case study. Journal Air Waste Management Association, 62 (1), 44-51. doi: 10.1080/10473289.2011.617599

Collados, E. \& Armijo, G. (2009). Impact of an Energy Refurbishment Programme in Chile: More than Energy Savings. In: D. Mumovic. \& M. Santamouris (eds). A Handbook of Sustainable Building Design and Engineering (pp. 401-422). London, United Kingdom: Earthscan.

Comisión Nacional de Energía - CNE. (2008). Política Energética: nuevos lineamientos. Transformando la crisis energética en una oportunidad. Santiago, Chile: Gobierno de Chile, Comisión Nacional de Energía. Recovered from https://www.cne.cl/archivos_bajar/Politica_Energetica_ Nuevos_Lineamientos_08.pdf

Comisión Nacional del Medio Ambiente - CONAMA (2004). Diseño de escenarios para apoyar la gestión del aire en Temuco y Padre las Casas. Santiago, Chile: CONAMA Región de la Araucanía. Recovered from http://metadatos.mma.gob.cl/sinia/articles-45966 recurso 1.pdf

Corporación de Desarrollo Tecnológico - CDT. (2010). Es tudio de Usos Finales y Curva de Oferta de Conservación de la Energía en el Sector Residencial de Chile. Informe final y resumen ejecutivo. Santiago, Chile: Corporación de Desarrollo Tecnológico y Cámara Chilena de la Construcción. Recovered from http://energiaabierta.cl/estudios

Corporación de Desarrollo Tecnológico- CDT. (2015). Medición del Consumo Nacional de Leña y Otros Combustibles Sólidos Derivados de la Madera. Informe final. Santiago, Chile: Santiago, Chile: Corporación de Desarrollo Tecnológico y Cámara Chilena de la Construcción y Ministerio de Energía. Recovered from http://energiaabierta. $\mathrm{cl} /$ estudios 
El Mercurio. (2014a). Solo 23\% de la leña que se consume en el sur de Chile tiene certificación. Diario El Mercurio, sección Nacional. Domingo 27 julio, 2014. Santiago, Chile.

El Mercurio. (2014b). El boom del pellet para calefacción demanda se duplica en una año y productores no logran abastecer el mercado. Diario El Mercurio, sección Economía y Negocios. Domingo 20 de julio, 2014. Santiago, Chile.

Gómez-Lobo, A., Lima, J., Hill, C. \& Meneses, M. (2005) Diagnóstico del Mercado de la Leña en Chile. Santiago, Chile: Centro de Microdatos, Universidad de Chile. Recovered from http://metadatos.mma.gob.cl/sinia/articles-50791_informe_final.pdf

Hofflinger, A., Boso, A. \& Oltra, C. (2019). The Home Halo Effect: how Air Quality Perception is Influenced by Place Attachment. Human Ecology, 47 (4), 589-600. doi 10.1007/s10745-019-00100-z

Ministerio de Energía - Minergía. (2014). Guía práctica para el buen uso de la leña: Leña seca - leña eficiente. Santiago, Chile: Gobierno de Chile. Recovered from http://www.energia.gob.cl/sites/default/files/guia buen_uso_de_la_lena_web.pdf

Ministerio Secretaría General de la Presidencia - Comisión Nacional del Medio Ambiente - Minsegpres - Conama. (1998a). Establece Plan de Descontaminación para el área circundante a la fundición de Caletones de la división el teniente de Codelco Chile. Santiago, Chile Gobierno de Chile. Recovered from https://mma.gob. $\mathrm{cl} /$ planes-de-descontaminacion-atmosferica-estrategia-2014-2018/

Ministerio Secretaría General de la Presidencia - Comisión Nacional del Medio Ambiente- Minsegpres - Conama. (1998b). Establece Plan de Prevención y Descontaminación para la Región Metropolitana. Santiago, Chile Gobierno de Chile. Recovered from https://mma.gob. $\mathrm{cl} /$ planes-de-descontaminacion-atmosferica-estrategia-2014-2018/

Ministerio Secretaría General de la Presidencia- Comisión Nacional del Medio Ambiente - Minsegpres - Conama. (1999). Establece Plan de Descontaminación para la zona circundante a la fundición de Potrerillos de la división Salvador de Codelco Chile. Santiago, Chile: Gobierno de Chile. Recovered from https://mma.gob.cl/planes-de-descontaminacion-atmosferica-estrategia-2014-2018/

Ministerio Secretaría General de la Presidencia- Minsegpres. (1999). Establece Plan de Descontaminación para las localidades de María Elena y Pedro de Valdivia. Santiago, Chile: Gobierno de Chile. Recovered from https://mma.gob.cl/planes-de-descontaminacion-atmosferica-estrategia-2014-2018/

Ministerio Secretaría General de la Presidencia - Minsegpres. (2001). Establece Plan de Descontaminación para la zona circundante a la fundición Chuquicamata de la división Chuquicamata de Codelco Chile. Santiago, Chile: Gobierno de Chile. Recovered from https://mma.gob.cl/planes-de-descontaminacion-atmosferica-estrategia-2014-2018/
Ministerio Secretaría General de la Presidencia - Minsegpres. (2010a). Revisa, reformula y actualiza Plan de Prevención y Descontaminación Atmosférica para la Región Metropolitana (PPDA). Santiago, Chile: Gobierno de Chile. Recovered from https://mma.gob.cl/planes-de-descontaminacion-atmosferica-estrategia-2014-2018/

Ministerio Secretaría General de la Presidencia - Minsegpres. (2010b). Establece Plan de Descontaminación At mosférica de Temuco y Padre Las Casas. Santiago, Chile: Gobierno de Chile. Recovered from https://mma.gob. $\mathrm{cl} /$ planes-de-descontaminacion-atmosferica-estrategia-2014-2018/

Ministerio de Vivienda y Urbanismo- Minvu. (2015). Llama a postulación en condiciones especiales, para el desarrollo de proyectos del "Programa especial para las comunas de Temuco y Padre Las Casas, sectores medios" año 2015. Santiago, Chile: Gobierno de Chile. Recovered from https://www.leychile.cl/Navegar?idNorma=1078310\&idVersion $=2015-06-11 \& r_{-}=4$

Ministerio del Medio Ambiente- MMA. (1992). Aprueba Plan de descontaminación del complejo industrial Las Ventanas propuesto conjuntamente por la empresa nacional de minería, fundición y refinería Las Ventanas y la planta termoeléctrica Chilegener. S.A. Santiago, Chile: Gobierno de Chile. Recovered from https://mma.gob.cl/ valparaiso/plan-de-descontaminacion-complejo-industrial-las-ventanas-1992/

Ministerio del Medio Ambiente- MMA. (2003). Reformula y actualiza Plan de Prevención y Descontaminación Atmosférica para la región Metropolitana (PPDA). Santiago, Chile: Gobierno de Chile. Recovered from https://www. leychile.cl/Navegar?idNorma=220650

Ministerio del Medio Ambiente- MMA. (2010). Establece Plan de descontaminación atmosférico para la ciudad de Tocopilla y su zona circundante. Santiago, Chile: Gobierno de Chile. Recovered from https://www.leychile.cl/Navegar?idNorma=1017753

Ministerio de Medio Ambiente - MMA. (2012). Informe del Estado del Medio Ambiente 2011. Santiago, Chile: Gobierno de Chile. Recovered from http://sinia.mma.gob.cl/ estado-del-medio-ambiente/

Ministerio de Medio Ambiente- MMA. (2013a). Evaluación del Plan de Descontaminación de Material Particulado Fino (MP2.5) para las Comunas de Temuco y Padre de Las Casas. GreenLab UC - DICTUC. Recovered from https://www.dictuc.cl/unidades/greenlab/

Ministerio del Medio Ambiente- MMA. (2013b). Establece Plan de Descontaminación Atmosférica para el Valle Central de la región del libertador general Bernardo O'Higgins. Santiago, Chile: Gobierno de Chile. Recovered from https://www.leychile.cl/Navegar?idNorma=1053451

Ministerio del Medio Ambiente- MMA. (2014a). Planes de Descontaminación Atmosférica. Estrategias 20142018. Santiago, Chile: Gobierno de Chile. Recovered from https://mma.gob.cl/planes-de-descontaminacion-atmosferica-estrategia-2014-2018/ 
Ministerio del Medio Ambiente - MMA. (2014b). Ministerio del Medio Ambiente. Establece Plan de descontaminación atmosférica para localidad de Andacollo y sectores aledaños. Santiago, Chile: Gobierno de Chile. Recovered from https://ppda.mma.gob.cl/wp-content/ uploads/2018/05/DS-59-2014-Plan-de-Descontaminacion-Atmosferica-para-la-localidad-de-Andacollo-y-sectores-aledanos.pdf

Ministerio del Medio Ambiente - MMA. (2015). Plan de descontaminación atmosférica por MP2.5, para las comunas de Temuco y Padre Las Casas y de actualización del plan de descontaminación por MP10, para las mismas comunas. Santiago, Chile: Gobierno de Chile. Recovered from https://ppda.mma.gob.cl/

Ministerio del Medio Ambiente- MMA. (2016a). Establece Plan de Descontaminación Atmosférica para la ciudad de Coyhaique y su zona circundante. Santiago, Chile: Gobierno de Chile. Recovered from https://www.leychile.cl/ Navegar?idNorma $=1133992$

Ministerio del Medio Ambiente- MMA. (2016b). Establece Plan de Descontaminación Atmosférica para las comunas de Talca y Maule. Santiago, Chile: Gobierno de Chile. Recovered from https://www.leychile.cl/Navegar?idNorma $=1088772 \&$ idParte $=0$

Ministerio del Medio Ambiente - MMA. (2016c) Establece Plan de Descontaminación Atmosférica para la comuna de Osorno. Santiago, Chile: Gobierno de Chile. Recovered from https://www.leychile.cl/ Navegar?idNorma $=1088771$

Ministerio del Medio Ambiente- MMA. (2016d). Establece Plan de Prevención y Descontaminación Atmosférica para las comunas de Chillán y Chillán Viejo. Santiago, Chile: Gobierno de Chile. Recovered from https://www. leychile.cl/Navegar?idNorma=1088773

Ministerio del Medio Ambiente- MMA. (2017). Calefactores Certificados.

Pérez, A., Flores, V. \& Calama, J. (2015). Comparison of Energy-Saving Restoration Costs Based on Spain's Initial Constraints [Single-Family Zone B4]. Journa of Construction. 14 (2), 44-50. doi 10.4067/S0718 $915 \times 2015000200006$

Platt, J. (1992). "Case Study" in American Methodological Thought. Current Sociology, 40 (1), 17-48. doi $10.1177 / 001139292040001004$

Reyes, R., Schueftan, A., Ruiz, C. \& González, A. (2019) Controlling air pollution in a context of high energy poverty levels in southern Chile: Clean air but colder houses? Energy Policy, 124 (1), 301-311. doi 10.1016/j. enpol.2018.10.022

Schueftan, A. \& González, A. (2013). Reduction of firewood consumption by households in south-central Chile associated with energy efficiency programs. Energy Policy, 63 (1), 823-832. doi 10.1016/j.enpol.2013.08.097

Schueftan, A. \& González, A. (2015). Proposals to enhance thermal efficiency programs and air pollution control in south-central Chile. Energy Policy, 79 (1), 48-57. doi 10.1016/j.enpol.2015.01.008

UFRO. (2009). Diseño de un Programa de Recambio de Artefactos Existentes que Combustionan Leña por Tecnología Menos Contaminante, en las Comunas de Temuco y Padre Las Casas. Universidad de la Frontera. Final Report (1285-11014-CO08). Temuco, Chile: Conama. 